\title{
Editorial
}

\section{Global cooperation resolve the covid-19 pandemic}

\author{
Benni Setiawan \\ Editor in Chief Informasi \\ bennisetiawan@uny.ac.id
}

Yuval Noah Harari (2020) writes very well The world after coronavirus. One interesting note from Harari is the need for global cooperation. Covid-19 has become a worldwide conversation and needs an integrated subscription.

Why global cooperation? Ohmae said the global world allows us to connect to facilitate the humanitarian movement. Earth is flat allows a pandemic to spread rapidly. This is rahmatan lin alamin's disease, borrowing the term Hajriyanto Y Thohari. A condition suffered by all people in the world.

When the world feels the same pain, global cooperation is vital. This is because humans are equipped with the knowledge to move together to resolve this problem.

Joint movements for humanity need to be echoed amid the increasingly individual society of today. Although the government is currently encouraging people to be psychologically provoked, a passion for helping one another needs to be a community spirit. Helping the neighbors with the food granary movement, giving what they have, buying what they sell, has become the spirit of the people of Indonesia.

However, Covid-19 needs an integrated global framework. Harari said that comprehensive work requires the support of science, government authority, and also the media. The three bodies need to work together with other forces, namely religious groups.

\section{Religionist}

Religious groups/mass organizations (mass organizations) have a significant role in moving people's awareness of moving. Running in the name of religion is often easier. Because religious people have an assumption with that, they get the reward of goodness (heaven).

Hans Kung, in global ethics, calls the role of religionists influential in a changing world. Religious authorities indeed find it easier to move the community in worldwide participation against Covid-19.

One example is the humanitarian work carried out by Muhammadiyah through the Muhammadiyah Covid-19 Comand Center (MCCC). MCCC, with all the resources owned by Muhammadiyah, is moving to assist the government in accelerating the handling of Covid-19. Muhammadiyah's real action can become a global social capital to help one another deal with this global pandemic.

What was done by Muhammadiyah became one of the pillars of preventing Covid-19 and building humanitarian cooperation? Muhammadiyah's attitude and actions prove that religion (wan) is still a significant force in solving every problem.

What is done by Muhammadiyah needs to get support from other communities? Kiai and 
Ustadz kampung need to be invited to the process of religious dialectics so that the spread of Covid-19 can stop. But this is indeed difficult, and our religious leaders are often not one word in constructing sentences (cultural/humanitarian work).

\section{Get rid of the ego}

Furthermore, Covid-19 can undoubtedly be a severe threat to civilization. As part of world civilization, they join hands to help, educate, and encourage new order. This new order has made it possible for the world and its life to remain sustainable after Covid-19. Nowadays, humans as thinking beings are challenged to find a breakthrough, so that Covid-19 does not destroy life.

The global world needs to be aware that Covid-19 is not just a local issue of a region or country. But this is a matter of humanity, a matter of problems ahead of a civilization.

The world needs to get rid of the ego. The ego of a country will only accelerate human extinction. The trade ego of drug sales, for example, needs to be eliminated in the subconscious of the state.

It is common knowledge that the existence of a virus will bring up trade competition; in this case, the sale and purchase of drugs. Medicine became merchandise that promised the coffers of state finances. Buying and selling drugs is more promising than trading weapons.

Therefore, the world needs to realize that Covid-19 is a humanitarian problem that needs to be parsed with humanity. Not even blame each other and or take the opportunity in the midst of suffering the world's population.

\section{Intellectual Role}

More than that, people will face the "new world" after Covid-19. The philosophy of cooperation and harmonious life has now begun to be interpreted differently from the original meaning. It is the deconstruction of purpose and even awareness in the Derrida language that will bring about new intellectual property.

This is an "intellectual" opportunity to contribute to the world by giving meaning and even finding new meaning in theology, ethics, law, and others. The original purpose is what can save humanity. That new meaning can make the world remain amid a global pandemic.

The discovery of new meanings will encourage a person to become Ulul Albab. The Koran refers to their Ulul Albab as those who continue to think and contribute to civilization, when they are young, approaching old, and already past, while continuing to pray to and ask Allah for forgiveness that the process was not easy (QS Ali Imran, 3: 191).

Besides this, the government needs to have communicators during a crisis. Crisis communication is one of the keys to success in unraveling the problem of Covid-19. Crisis communication requires the government to be an excellent communicator. Every information needs to be appropriately conveyed and correctly so as not to cause panic. Panic needs to be prevented so that the public will understand more about Covid-19.

The ability to manage information and convey it accurately and correctly is the key to successful crisis communication. Crisis communication is essential so that people become a joint force against Covid-19.

The world is now waiting for the progress of all parties to unravel Covid-19. It is time to stop all debates. It's time to think and act to save lives from Covid-19.

In the end, the design of global cooperation by involving all parties - including the clergy in it -, removing the ego, and removing economic/political trade interests, can save the world from misfortune. The world will live on with the spirit of mutual life. Vision, please help with a better experience. 